\title{
Front Matter: Volume 8992
}

, "Front Matter: Volume 8992," Proc. SPIE 8992, Photonic Instrumentation Engineering, 899201 (3 April 2014); doi: 10.1117/12.2063969

SPIE. Event: SPIE OPTO, 2014, San Francisco, California, United States 


\section{PROCEEDINGS OF SPIE}

\section{Photonic Instrumentation Engineering}

Yakov G. Soskind

Craig Olson

Editors

2-5 February 2014

San Francisco, California, United States

Sponsored and Published by

SPIE 
The papers included in this volume were part of the technical conference cited on the cover and title page. Papers were selected and subject to review by the editors and conference program committee. Some conference presentations may not be available for publication. The papers published in these proceedings reflect the work and thoughts of the authors and are published herein as submitted. The publisher is not responsible for the validity of the information or for any outcomes resulting from reliance thereon.

Please use the following format to cite material from this book:

Author(s), "Title of Paper," in Photonic Instrumentation Engineering, edited by Yakov G. Soskind, Craig Olson, Proceedings of SPIE Vol. 8992 (SPIE, Bellingham, WA, 2014) Article CID Number.

ISSN: 0277-786X

ISBN: 9780819499059

Published by

SPIE

P.O. Box 10, Bellingham, Washington 98227-0010 USA

Telephone +1 3606763290 (Pacific Time) · Fax +1 3606471445

SPIE.org

Copyright @ 2014 , Society of Photo-Optical Instrumentation Engineers.

Copying of material in this book for internal or personal use, or for the internal or personal use of specific clients, beyond the fair use provisions granted by the U.S. Copyright Law is authorized by SPIE subject to payment of copying fees. The Transactional Reporting Service base fee for this volume is $\$ 18.00$ per article (or portion thereof), which should be paid directly to the Copyright Clearance Center (CCC), 222 Rosewood Drive, Danvers, MA 01923. Payment may also be made electronically through CCC Online at copyright.com. Other copying for republication, resale, advertising or promotion, or any form of systematic or multiple reproduction of any material in this book is prohibited except with permission in writing from the publisher. The CCC fee code is 0277-786X/14/\$18.00.

Printed in the United States of America.

Publication of record for individual papers is online in the SPIE Digital Library.

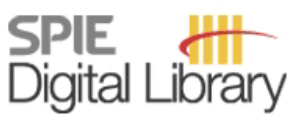

SPIEDigitalLibrary.org

Paper Numbering: Proceedings of SPIE follow an e-First publication model, with papers published first online and then in print and on CD-ROM. Papers are published as they are submitted and meet publication criteria. A unique, consistent, permanent citation identifier (CID) number is assigned to each article at the time of the first publication. Utilization of CIDs allows articles to be fully citable as soon as they are published online, and connects the same identifier to all online, print, and electronic versions of the publication. SPIE uses a six-digit CID article numbering system in which:

- The first four digits correspond to the SPIE volume number.

- The last two digits indicate publication order within the volume using a Base 36 numbering

system employing both numerals and letters. These two-number sets start with 00, 01, 02, 03, 04,

05, 06, 07, 08, 09, 0A, OB ... 0Z, followed by 10-1Z, 20-2Z, etc.

The CID Number appears on each page of the manuscript. The complete citation is used on the first page, and an abbreviated version on subsequent pages. Numbers in the index correspond to the last two digits of the six-digit CID Number. 


\section{Contents}

vii Conference Committee
ix Introduction

\section{SESSION 1 SENSORS AND RUGGEDIZED SYSTEMS I}

899202 Automated design tools for biophotonic systems (Invited Paper) [8992-1]

G. Vacca, Kinetic River Corp. (United States); H. Lehtimäki, Plan Energy Ltd. (Finland);

T. Karras, Design Parametrics, Inc. (United States); S. Murphy, SKMurphy, Inc. (United States)

899203 Miniature near-infrared spectrometer for point-of-use chemical analysis [8992-2]

D. M. Friedrich, C. A. Hulse, M. von Gunten, E. P. Williamson, C. G. Pederson, N. A. O'Brien, JDSU (United States)

\section{SESSION 2 SENSORS AND RUGGEDIZED SYSTEMS II}

899208 Influence of laser frequency noise on scanning Fabry-Perot interferometer based laser Doppler velocimetry [8992-6]

P. J. Rodrigo, C. Pedersen, Technical Univ. of Denmark (Denmark)

899209 SPR based three channels fiber optic sensor for aqueous environment [8992-7]

R. Verma, B. D. Gupta, Indian Institute of Technology Delhi (India)

8992 0A Fiber optic surface plasmon resonance based ethanol sensor [8992-8]

R. Verma, B. D. Gupta, Indian Institute of Technology Delhi (India)

8992 OB Graphene-based all-fiber-optic temperature sensor [8992-9]

H. Lu, Z. Tian, S. Jin, J. Yu, G. Liao, J. Zhang, J. Tang, Y. Luo, Z. Chen, Jinan Univ. (China)

\section{SESSION 3 PERFORMANCE VERIFICATION AND CHARACTERIZATION I}

8992 OC Compact large-aperture Fabry-Perot interferometer modules for gas spectroscopy at midIR [8992-10]

U. Kantojärvi, A. Varpula, T. Antila, C. Holmlund, J. Mäkynen, A. Näsilä, R. Mannila,

A. Rissanen, J. Antila, VTT Technical Research Ctr. of Finland (Finland); R. J. Disch,

T. A. Waldmann, SICK AG (Germany)

8992 OD Measuring the refractive index with precision goniometers: a comparative study [8992-11] S. Krey, D. Off, A. Ruprecht, TRIOPTICS GmbH (Germany)

8992 OE Point-spread function-based characterization of optical systems [8992-12]

Y. G. Soskind, R. P. Walvick, C. D. Giranda, D. N. Laslo, R. Gifford, DHPC Technologies, Inc. (United States) 
8992 OF Automated assembly of camera modules using active alignment with up to six degrees of freedom [8992-13]

K. Bräuniger, D. Stickler, D. Winters, C. Volmer, M. Jahn, S. Krey, TRIOPTICS GmbH (Germany)

$8992 \mathrm{OH} \quad$ Automated multi-point analysis with multi-angle photometric spectroscopy [8992-15]

T. C. Burt, J. Comerford, C. Bricker, A. Hind, D. L. Death, Agilent Technologies Australia (Australia)

\section{SESSION 4 PERFORMANCE VERIFICATION AND CHARACTERIZATION II}

8992 Ol High-performance high-speed spectrum analysis of laser sources with SWIFTS technology [8992-16]

F. Thomas, Resolution Spectra Systems (France) and Institut de Planétologie et d'Astrophysique de Grenoble (France); M. De Mengin, Institut de Planétologie ef d'Astrophysique de Grenoble (France); C. Duchemin, Resolution Spectra Systems (France); E. Le Coarer, Institut de Planétologie et d'Astrophysique de Grenoble (France); C. Bonneville, T. Gonthiez, Resolution Spectra Systems (France); A. Morand, P. Benech, IMEP-LAHC (France); J.-B. Dherbecourt, ONERA (France); E. Hardy, E. Morino, R. Puget, B. Martin, Resolution Spectra Systems (France)

8992 0J Image transport using Anderson localized modes in disordered optical fibers [8992-18] S. Karbasi, R. J. Frazier, Univ. of Wisconsin-Milwaukee (United States); K. W. Koch, Corning Inc. (United States); T. Hawkins, J. Ballato, Clemson Univ. (United States); A. Mafi, Univ. of Wisconsin-Milwaukee (United States)

8992 OL Viewports for vacuum applications: correlation between viewport thickness and stress induced birefringence [8992-20]

A. Becker, J. Weber, M. Flämmich, U. Bergner, Vakuum Komponenten \& Messtechnik GmbH (Germany)

\section{SESSION $5 \quad$ LASER-BASED PHOTONIC INSTRUMENTATION I}

899200 Absolutely referenced distance measurement by combination of time-of-flight and digital holographic methods (Invited Paper) [8992-23]

M. Fratz, Fraunhofer-Institut für Physikalische Messtechnik (Germany); C. Weimann, Karlsruher Institut für Technologie (Germany); H. Wölfelschneider, Fraunhofer-Institut für Physikalische Messtechnik (Germany); C. Koos, Karlsruher Institut für Technologie (Germany); H. Höfler, Fraunhofer-Institut für Physikalische Messtechnik (Germany)

\section{SESSION 6 LASER-BASED PHOTONIC INSTRUMENTATION II}

$89920 Q$ Ultrahigh wavelength range $(300 \mathrm{~nm}-2 \mu \mathrm{m})$ polarization-independent $500 \mathrm{gs} / \mathrm{s}$ single-shot pulse, all-optical real time oscilloscope [8992-25]

J-F. Gleyze, CEA, CESTA (France); S. Hocquet, D. Monnier Bourdin, Greenfield Technology (France); P. Le Boudec, R. Arnaud, IDIL Fibres Optiques (France); B. Chassagne, A. Jolly,

ALPhANOV (France); D. Penninckx, CEA, CESTA (France) 
8992 OR Spectroscopy-based photonic instrumentation for the manufacturing industry: contactless measurements of distances, temperatures, and chemical composition [8992-26]

B. Noharet, E. Zetterlund, O. Tarasenko, M. Lindblom, Acreo Swedish ICT AB (Sweden);

J. Gurell, A. Bengtson, P. Lundin, Swerea KIMAB (Sweden)

8992 OS Developing dual-beam laser Doppler interferometry system for opto-piezoelectric materials based ultrasonic parking sensors and optofluidics sensors [8992-27]

P.-C. Lai, C.-K. Lee, National Taiwan Univ. (Taiwan)

8992 OT Impact of primary aberrations on coherent lidar performance [8992-28]

Q. Hu, P. J. Rodrigo, Technical Univ. of Denmark (Denmark); T. F. Q. Iversen, Winar Photonics A/S (Denmark); C. Pedersen, Technical Univ. of Denmark (Denmark)

\section{POSTER SESSION}

8992 OU Improvement of image quality by polarization mixing [8992-29]

R. Kasahara, I. Itoh, H. Hirai, Ricoh Co., Ltd. (Japan)

8992 OV Single-snapshot 2D color measurement by plenoptic imaging system [8992-30]

K. Masuda, Y. Yamanaka, G. Maruyama, S. Nagai, H. Hirai, Ricoh Co., Ltd. (Japan);

L. Meng, I. Tosic, Ricoh Innovations, Inc. (United States)

8992 OW Six-axis interferometric coordinates measurement system for nanometrology [8992-31] J. Hrabina, J. Lazar, Institute of Scientific Instruments of the ASCR, v.v.i. (Czech Republic); P. Klapetek, M. Valtr, Czech Metrology Institute (Czech Republic); O. Cip, J. Oulehla, M. Cizek, M. Hola, M. Sery, Institute of Scientific Instruments of the ASCR, v.v.i. (Czech Republic)

8992 0X Interferometric measurement system for cost effective e-beam writer [8992-32] Š. Řeřucha, M. Šarbort, M. Čížek, J. Hrabina, J. Lazar, O. Číp, Institute of Scientific Instruments of the ASCR, v.v.i. (Czech Republic)

Author Index 


\title{
Conference Committee
}

\author{
Symposium Chairs
}

David L. Andrews, University of East Anglia Norwich (United Kingdom)

Alexei L. Glebov, OptiGrate Corporation (United States)

Symposium Co-chairs

Jean Emmanuel Broquin, IMEP-LAHC (France)

Shibin Jiang, AdValue Photonics, Inc. (United States)

Program Track Chair

Yakov Sidorin, Quarles \& Brady LLP (United States)

Conference Chairs

Yakov G. Soskind, DHPC Technologies (United States)

Craig Olson, L-3 Communications (United States)

Conference Program Committee

James B. Breckinridge, California Institute of Technology (United States)

James T. A. Carriere, Ondax, Inc. (United States)

John Corless, Verity Instruments, Inc. (United States)

David G. Fischer, NASA Glenn Research Center (United States)

Filipp V. Ignatovich, Lumetrics, Inc. (United States)

Jacob B. Khurgin, Johns Hopkins University (United States)

Nada A. O'Brien, JDSU (United States)

Alain Villeneuve, Genia Photonics Inc. (Canada)

\section{Session Chairs}

1 Sensors and Ruggedized Systems I

James T. A. Carriere, Ondax, Inc. (United States)

2 Sensors and Ruggedized Systems II

Nada A. O'Brien, JDSU (United States)

3 Performance Verification and Characterization I

Craig Olson, L-3 Communications (United States) 
4 Performance Verification and Characterization II Filipp V. Ignatovich, Lumetrics, Inc. (United States)

5 Laser-based Photonic Instrumentation I

Yakov G. Soskind, DHPC Technologies (United States)

6 Laser-based Photonic Instrumentation II

Alain Villeneuve, Genia Photonics Inc. (Canada) 


\section{Introduction}

These inaugural proceedings for the Conference on Photonic Instrumentation Engineering present a record of a multidisciplinary forum for the measurement of light and its exploitation as a measurement tool. Light serves as a foundation of life, provides us with the ability to observe the world, and satisfies our curiosity to explore the world. The ability of humanity to question and explore the world around us is one of our most unique defining traits. In particular, the development of tools and instruments to measure and quantify the world around us is, in a large sense, what enables modern science and engineering, hearkening back to the days of the Royal Society itself.

In its most primeval form, light has been used since antiquity for measurement purposes, ranging from the ancient seafaring art of celestial navigation by starlight to the most modern of concepts, measurement of the finite speed of light itself. The first determination of the speed of light in 1676 was a major breakthrough in the recognition of our position in the universe. By timing motion in the moons of Jupiter, the Danish astronomer Ole Roemer put a finite time scale to the most fleeting of events -- the motion of photons through physical space. It is perhaps coincidental that almost concurrently (at least in historical terms) with the determination of the most important property about light, the first light-based microscope instruments were being employed in the Netherlands to discover the vast treasure of microbial life. In the late $18^{\text {th }}$ century, optical instrumentation helped to provide the first official definition of the meter, perhaps the most fundamental physical constant in science. Over the past 400 years and counting, the explosion in optical instrumentation has not ceased.

Measurements by or about light represent science on both the smallest and largest scales, and such diversity is well represented in the papers within this conference. There are papers representing all aspects of science, engineering systems, and measurement regimes. Optical instruments are presented within this conference ranging in size from the Giant Magellan telescope (designed to measure the extent of physical phenomena on the order of light years) to electron-beam lithography measurement tools providing single-nanometer accuracy. A series of ruggedized instruments is presented that are designed to work in the harshest environments: near molten steel, immersed in chemical media, withstanding high vacuum, and on top of wind turbines on the open sea. Presentations exploiting both high order (in the form of semiconductors and fiber Bragg gratings) and designed disorder (in the form of Anderson localized modes for light transport) conspire to illustrate how photonic systems can easily employ widely disparate physical phenomena. The design and development of photonic instrumentation systems for sustained life are represented as well, manifested in presentations on design tools for biophotonics and in situ fiber sensing for biological environments. 
Even within the realm of optics and photonics, the interdisciplinary nature of instrumentation systems, techniques, and physical phenomena is growing with exponential complexity. Providing a common ground and forum for new ideas to spread between the fundamental and the practical is critical to the continuation of science and engineering. We hope to see a strong and continuing interest in such a wide range of optical instrumentation, as well as the engineering required to realize it.

Yakov G. Soskind Craig Olson 